\title{
Fortes in Fide-The Role of Faith in the Heroic Struggle against Communism
}

\author{
Terézia Rončáková (D)
}

Citation: Rončáková, Terézia. 2021 Fortes in Fide-The Role of Faith in the Heroic Struggle against Communism. Religions 12: 837. https://doi.org/10.3390/rel12100837

Academic Editors: Michal Valčo, Jove Jim S. Aguas and Kamil Kardis

Received: 30 August 2021

Accepted: 29 September 2021

Published: 8 October 2021

Publisher's Note: MDPI stays neutral with regard to jurisdictional claims in published maps and institutional affiliations.

Copyright: (c) 2021 by the author Licensee MDPI, Basel, Switzerland. This article is an open access article distributed under the terms and conditions of the Creative Commons Attribution (CC BY) license (https:// creativecommons.org/licenses/by/ $4.0 /)$
Department of Journalism, Catholic University, 03401 Ružomberok, Slovakia; terezia.roncakova@ku.sk

\begin{abstract}
Repression and persecution by the totalitarian communist regimes have significantly affected the fates of Christian churches and believers in the countries of the "Eastern Bloc". Many members of the clergy and laypersons were incarcerated, tortured and persecuted, several bishops suffered exemplary punishment in the propaganda-driven show trials and a few of them were later beatified or canonized across the world (by the Catholic Church). Focusing on the literature originating in Slovakia, this meta-report aimed to summarize the key authors' essential works and to examine the question as to whether-and to what extent-faith was a contributing factor in the collapse of the communist regime. What was the role of the churches and believers in the struggle against communism? How and to what extent believers were involved in the resistance movements and the political and economic transformation of their countries that were set in motion by the collapse of those regimes? Based on an analysis of hundreds of books and articles on the subject, essential ideas were extracted, categorized and presented. The works of the persecuted authors were the subject of a detailed qualitative content analysis. Thus, four overarching dimensions (philosophical, intimate, personal and social/political) and fourteen categories related to the experience of faith were identified.
\end{abstract}

Keywords: communism; totalitarian regime; Slovakia; church; Christians; persecution; freedom

\section{Introduction}

"Your faith has healed you" - this recurring phrase of the Gospel (Mt 9:22; Mk 5:34; Mk 10:52; Lk 7:50; Lk 8:48; Lk 17:19; Lk 18:42) illuminates the essential role that faith plays in the life of a believing Christian. Within the realm of Christian theology, faith has the power to effect a profound transformation of one's life and behavior in specific circumstances. This is an obvious fact because people always think and act based on what they believe. Faith is not just an abstract philosophical proposition about what does or does not exist "above us"; it is "a decision involving one's whole existence. It is an encounter, a dialogue, a communion of love and of life between the believer and Jesus Christ, the Way, and the Truth, and the Life (cf. In 14:6). It entails an act of trusting abandonment to Christ, which enables us to live as he lived (cf. Gal 2:20), in profound love of God and of our brothers and sisters" (Paul 1993; Veritatis splendor, Art. 88).

The key question addressed herein is the role of faith in the struggle against communism in Slovakia in the period $1945^{1}-1989$. Naturally, within the cultural context of Slovakia (and, for that matter, Czechoslovakia), we limited our examination solely to the implications of the Christian faith that was lived in various church communities in Slovakia (mainly Catholic-both Roman and Greek, but also Lutheran and other Protestant churches). The role of faith in the struggle for freedom was examined as part of the Faith and Freedom project ${ }^{2}$. It also included gathering testimonies (oral history) in the form of in-depth interviews and performing a comprehensive review of existing literature on the subject. The corpus of works is gradually amended and it currently contains 405 items, which means that, to some extent, it can already be regarded as representative. A quantitative analysis of the corpus of literature was presented elsewhere (Rončáková 2021) 
with a focus on the chronology of publications on faith and struggle against communism in Slovakia; a composition of the literature in terms of genre, topic and stories of the people covered; and the most prolific authors and publishers on the subject. Here, we will focus on the central ideas concerning faith contained in those works.

\section{Methodology and State of the Art}

We distilled the key categories of the role of faith in the heroic struggle against communism from the literature on the subject using the method of qualitative content analysis. This included a thorough reading of essential books and articles and identifying the overlaps and recurring ideas. This effort was by no means simple as the categories had to be extracted from various subjective reflections or texts covering the subject only partially (Table 1). The autobiographies and biographies subject to our review (172 in total) usually included facts and stories, which were rather scarcely intertwined with reflections on faith. Monographs and collections of works (113 in total), as well as scholarly studies (112 in total), usually focused on various aspects of key historic events, with the underlying questions, such as faith, bubbling under the surface as an essential determinant but not addressed explicitly by the authors.

Table 1. Number of publications.

\begin{tabular}{lrr}
\hline Genre & Total & Slovak Publications \\
\hline Memoirs & 116 & 101 \\
\hline Biographies & 73 & 73 \\
\hline Monographs & 99 & 86 \\
\hline Edited collections & 27 & 27 \\
\hline Studies and articles & 128 & 112 \\
\hline Documents & 7 & 7 \\
\hline Total & 450 & 406 \\
\hline
\end{tabular}

Obviously, in addition to the corpus of literature that was subject to this review, there are many other works available that in one way or another cover the personal fates of people suffering during communism; however, those works were not considered, at least directly, because they did not address (to the extent we considered relevant) faith and its role per se. Nevertheless, they were regarded for the purpose hereof as additional supporting literature. This category included sources covering general history (Kováč et al. 1999; Lettrich 1993; Lipták 1998); Slovak exile (Braxátor 1992); philosophical, sociological or political essays (Kusý 1990; Letz 1996; Šimečka 1990; Šimko 1994; Zemko 2002); memoirs of politicians (Gašpar 1998; Chňoupek 1998), artists (Mittelman-Dedinský 2001), publicists (Ottmar 1996), political prisoners without religious background; and novels (both autobiographical and fictional).

As the first step, the publications were sorted into chronological order (Figure 1). Of course, prior to 1990, this genre was published only rarely-these included books printed abroad and illegally smuggled into Slovakia. This portion of the literature review is not represented systematically and it remains quite random; in addition, the works published in Slovakia as samizdat were excluded. The corpus of texts includes those from the period after 1990. In the early 1990s, publishers focused mainly on memoirs and autobiographies. In the late 1990s, the number of publications increased, mainly due to new monographs and biographies. After 2001, one can observe a drop in the publication activity, but after 2006, the number of published materials has increased significantly. Today we are going through the most prolific period in terms of new publications on the given subject. 


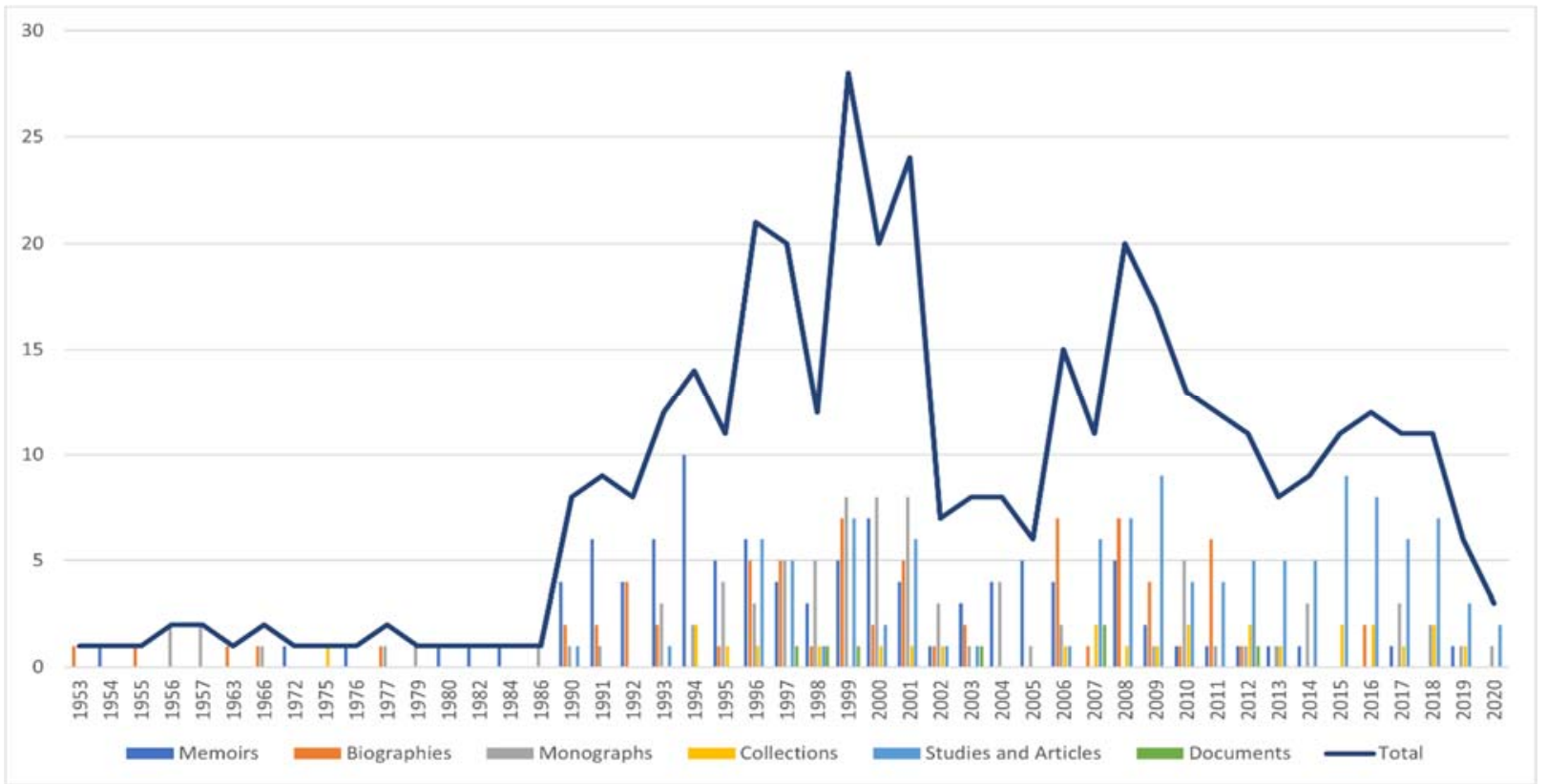

Figure 1. Timeline of publications.

An abundance of scholarly literature is available on the role of faith in society in different contexts that are not specifically related to the struggle against communism. I. Gazda, for instance, focused on the potential of using personal stories or testimonies of God in media for evangelization purposes (Gazda 2012), T. Rončáková suggested that some culture war attitudes cannot be understood beyond the domain of faith (Rončáková 2018), J. R. de Oliveira examined the role of the church from the perspective of humane geography with a focus on the new dynamics of the hyper-modern societies and spatial cyber-transformation (de Oliveira 2019), H. Tkáčová explored the unity and the entirety of faith and human life in the context of postmodern culture (Tkáčová 2014), M. Gavenda discussed the significance of faith in the integral healing of current visual culture (Gavenda 2016), J. E. Hagan examined the impact of faith on the emotions of sportspersons (Hagan 2021) and various other works addressed the role of faith in science (e.g., Valčo and Boehme 2017) or the role of faith in coping with difficult life situations (Desrosiers 2020, for instance, examined the role of faith in the life of long-term HIV survivors). Furthermore, there is a whole array of sociological studies on the role of faith in various aspects of life (in the Slovak context, these were summarized, e.g., in Tížik and Zeman (2017)).

The aim of our research was to examine the role of faith in the heroic struggle against communism in Slovakia. Based on the review mentioned above and a detailed examination of the history of the church in Czechoslovakia during communism, the following ten essential works from the key actors of the so-called "hidden church" and dissent were selected: František Mikloško, Ján Čarnogurský, Ján Chryzostom Korec, Silvester Krčméry, Tomislav Poglajen Kolakovič ${ }^{3}$, Marián Gavenda ${ }^{4}$, Anton Neuwirth, Oto Mádr, Bohumil Vít Tajovský and Ladislav Kubíček. These are the key figures of the Slovak and Czech churches, as well as Christian democratic politics. Primary sources were amended using secondary literature, i.e., works focusing on individual figures, such as J. Palaščák's account of the life of Ján Chryzostom Korec, K. Himmerová's work on the imprisoned nuns and A. Drda's account of the story of Augustín Navrátil.

Selected works were made subject to a detailed qualitative analysis in line with the rules required by this method (Hornig Priest 1996, p. 114). Based on the analysis, 14 categories covering the role of faith in the struggle against communism were identified. The formulation of individual categories was determined by the key question of our research: What was the essential and most significant aspect of experiencing faith by these leaders in the context of the communist repression? Fourteen categories were rearranged 
based on their inherent interrelations and allocated into four interpretative dimensions; the ideas of witness, martyrdom and sacrifice were sustained as the primary underlying basis for all four dimensions (Table 2).

Table 2. Research categories.

\begin{tabular}{|c|c|c|c|}
\hline & $\begin{array}{l}\text { Overarching } \\
\text { Dimension }\end{array}$ & Category & Occurrences \\
\hline 1. & \multicolumn{2}{|c|}{ Witness, martyrdom and sacrifice } & 4 \\
\hline 2. & \multirow{3}{*}{ Philosophical } & The danger of comfort & 4 \\
\hline 3. & & The essence of being human & 5 \\
\hline 4. & & Truth & 2 \\
\hline 5. & \multirow{4}{*}{ Intimate } & Communion with God & 6 \\
\hline 6. & & Primacy of faith & 7 \\
\hline 7. & & God's will and the Cross & 3 \\
\hline 8. & & Faith as a source of support and meaning & 3 \\
\hline 9. & \multirow{3}{*}{ Personal } & Human maturity & 3 \\
\hline 10. & & Humility & 4 \\
\hline 11. & & Internal freedom & 3 \\
\hline 12. & \multirow{3}{*}{ Social and political } & Indivisibility of faith and life & 2 \\
\hline 13. & & Driving force of the society & 4 \\
\hline 14. & & Reconciliation and forgiveness & 4 \\
\hline
\end{tabular}

The table above also includes the number of occurrences of individual topics in the works that were subject to the review. However, for the purpose of this study, the quantitative element is not of primary importance, it is only regarded as secondary. For the sake of being succinct and understandable, only the relevant passages are quoted in the descriptions of individual categories below.

\section{Results}

Each of the individual categories outlined above is discussed in more detail in the following sections.

\subsection{Witness, Martyrdom and Sacrifice}

Throughout the history of the church, people of strong character willing to suffer or even give one's life for the matter of faith have always been called martyrs or witnesses. The term "witness" is hardly used in secular language, and if it is, it often signifies a role in the court proceedings. Within the realm of religion, however, this term encapsulates total devotion to God, even to the point of one's own suffering or death. A martyr, who is sometimes referred to as "a witness of faith", takes on that challenge; the term "witness" is used by several authors to refer to the main characters of their works, the believing heroes who fought against communism (Tajovský 2009, p. 9; Gavenda 2017, pp. 2-3; Mikloško 2013, p. 33). The use of this term was also indirectly endorsed by Pope John Paul II, who wrote a personal note to one of the most significant figures of the Slovak religious dissent, Silvester Krčméry. Krčméry had asked the pope to write a dedication into his book To nás zachránilo [This is What Saved Us] (Krčméry 1995). The pope agreed and he used the phrase "true witness of Christ and the Church" (Mikloško 2013, p. 182).

The attitude of total fidelity to God leads a martyr to refuse to negotiate for any concessions. For a martyr, the temptation to negotiate is suppressed as this might be viewed as partial acceptance of the arguments of the enemy. This pattern was also present 
in S. Krčméry's famous defense in the final phases of his trial in 1954, after which, he was sentenced to 14 years in prison:

And so if I am about to be punished for what I did, i.e., for the good, the truth and Christ, then I do not want a lower penalty but rather a higher penalty and I would be the happiest person on earth if I could die for Christ-although I know I am not worthy of such a great grace. Therefore I do not wish to take advantage of any mitigating circumstances for myself just like I cannot apologize for doing what was good. (Krčméry 2015, online)

Witnesses of faith typically take the attitude of sacrifice. S. Krčméry admitted that during the time of heightened international tensions, he, along with his fellow prisoners, declared their willingness to accept even longer penalties in prison or even death to avoid nuclear war (Mikloško 2013, p. 179). While in prison, at one point, he even sacrificed the Slovak nation for the conversion of Russia and China (Mikloško 2013, p. 178). Oto Mádr, who was another political prisoner a significant figure of the Czech church, compared such voluntary sacrifices of believers to the kernel of wheat that falls to the ground and dies and, according to the Gospel (Jn 12:21), eventually bears much fruit in both personal life and political history (Mádr 1992, p. 206).

\subsection{The Danger of Comfort}

The veneration of martyrs in times of peace and prosperity works as a kind of "spiritual antivirus": it protects us against the "danger of unhealthy secularization", against sloppiness and loss of evangelical radicalism (Gavenda 2017, p. 2). That is why Pope John Paul II, at the beginning of the third millennium, called upon the post-communist countries to develop a kind of "new martyrology" (Paul 1994, Tertio millennio adveniente, Art. 37).

Internal inertia is one of the key warnings from those who suffered during communism. They find inertia as the key enemy of the radical attitude to life and, at the same time, the main prerequisite for the rise of communist regimes or any other regimes throughout history. Anton Neuwirth, one of the Slovak political prisoners, who later became a politician, suggested that the training of resilience to sensual pleasure is critical, even in prison. Neuwirth never ate everything on his plate but he always left one spoon of his meal untouched (of course, his fellow prisoner, with whom Neuwirth shared his cell and who served the regime as an informer, was always ready to jump at the plate and eat up the rest) (Neuwirth and Lesňák 2001, p. 61).

This tendency to conformity is even a bigger challenge during the time of freedom, peace and relative prosperity. This idea was suggested shortly after the Second World War by an enigmatic figure and visionary priest called Tomislav Kolakovič, who inspired a generation of followers of his movement Rodina (The Family) in Slovakia and the Czech Republic: "Today people who possess are in fact possessed by-and enslaved to-their possessions" (Kolakovič-Poglajen 1993, p. 60). Ján Chryzostom Korec, the Slovak secret bishop, who later became cardinal, accused the communist regime of wiping out the spirit from the human body and filling it with sensual experiences: "When people fail to acknowledge the primacy of spirit and spiritual values, they are no longer surprised by any crime or massacre of people. They start embracing sensual experiences and soon they are willing to sacrifice justice and truth" (Korec 1991, p. 336).

\subsection{The Essence of Being Human}

Communism is destructive and aims at the "essence" of what makes us human (Tajovský 2009, p. 9). Virtually all authors of the reviewed books pointed to the intention of the ideology to eliminate something very fundamental in human beings. A. Neuwirth called it neopaganism and compared it to Nazism. Both systems were characterized by "adoration", whether it was the race or a class. "No reasonable person should ever agree to such proposition because it is an abuse of the human natural order. All the more for believers who should be able to see that such a system of thought is contradictory to any religion" (Neuwirth and Lesňák 2001, p. 87). Believers are specifically equipped to identify this danger and, during 
communism, they accepted their duty to actively stand up against the evil, regardless of the risk (Mádr 1992, p. 213):

Once a political program turns into a philosophy or religion, when it tries to embrace human beings in their entirety, get hold of their soul and conscience while at the same time breach their fundamental freedoms, destroy spiritual values, trample on religion, dismiss God and coerce people to accept all of that, then it is the duty of the Church to defend the rights of both human and God's laws. (Korec 1987, p. 44)

Believers' basic understanding during communism was that, regardless of the opinion of the majority, the fundamental problem of destruction, at its core, is the apostasy from Christ: "a kind of naive childish attempt to remove Christ from all spheres of our lives" (KolakovičPoglajen 1993, p. 50).

\subsection{Truth}

In this respect, several authors used the phrase "we hold the truth", which, given the current understanding of the truth, may sound quite controversial ${ }^{5}$. The final words of the famous speech of S. Krčméry before the communist court ended with an exclamation: "You hold the power in your hands, but we hold the truth!" (Krčméry 2015, online). Bishop J. Ch. Korec wrote: "You hold the upper hand but we hold the truth" (Korec 1993, p. 243). Both writers also added that, whereas power usually runs dry, the truth prevails, and the truth will always rise from the dead. In this sense, they warned that the idea of "liberation" from God's truth inevitably leads to a decline, new serfdom of lawlessness and injustice (Korec 1991, p. 244).

It should be noted that from the perspective of a believing person, the term "truth" is closely associated with Jesus Christ. In this sense, we should bring some rigor into the use of language. As Pope Benedict XVI concluded it would be more appropriate to say "the truth possesses me" rather than "I possess the truth" (Seewald 2010, p. 62). Hence, a believer should strive for "being possessed by the truth". However, in today's societies "having a clear faith based on the Creed of the Church is often labelled as fundamentalism. Whereas relativism, that is, letting oneself be 'tossed here and there, carried about by every wind of doctrine', seems the only attitude that can cope with modern times" (Ratzinger 2005, online).

\subsection{Communion with God}

Regarding the reflections on possessing the truth, we may turn our attention directly to the definition of faith (by quoting John Paul II). One of the typical features of witnesses of faith was their experience of a "breathtaking adventure of love between man and God" (Mádr 1992, p. 106), an "intimate relationship with God" (Korec 1993, p. 411) or a "permanent communion with God through the experience of unity with God which preserves one's identity and protects a person from losing dignity" (Neuwirth and Lesňák 2001, p. 123).

Several authors pointed to Silvester Krčméry as a good example of such communion with God (Mikloško 2013, p. 173; Neuwirth and Lesňák 2001, p. 123):

I had the honour to meet him in Bratislava several times. Just like with Mother Theresa or Dorothy Day you know that you are walking in the presence of someone in whom God is present, someone who is able to do unusual things. Silvester Krčméry was surrounded by God's presence, it was like some sort of radiation without the aura; you could sense it rather than see it. (Novak 2014, p. 398)

However even among "common" believers, who have not attained such unity with God, faith in one God provided an important underlying framework or basis for the development of both individuality and community. J. Čarnogurský used the term "ideological background" to describe this discerning feature between secular and religious dissent. The background of secular people was colorful and pluralistic, for believers it was "monolithic" and consisted in "living out Christianity" (Čarnogurský 1990, p. 135). 


\subsection{Primacy of Faith}

Strong personal faith was absolutely crucial for persecuted believers; it prevailed over fear, even over the fear of death. S. Krčméry wrote that "once he was able to free himself from the fear of death and silently accepted the fact that death would eventually come anytime his incarcerators decide to do so, he felt how the power is being transferred onto him. Hence they were no longer able to deter him" (Novak 2014, p. 398-99). John Paul II posed an important question: What is it that makes a person so strong and resilient? What is "the common secret" of the heroes of faith?

I believe it is determination in faith. The primacy of faith in one's entire life and every action, courageous faith free of fear, hard-bitten faith through trials, faith brave enough to follow any God's challenge-fortes in fide. (Paul 2004, p. 123)

For people who were "strong in faith", it was a matter of course to suffer and die for something that they regarded as more precious than their own life (Mádr 1992, pp. 44, 203). "They regarded values for which they suffered as something more than anything else including freedom" (Palašćák 2006, p. 46). Hence, they were able to joyfully engage in the "deeds of Gandhi" for a noble cause that transcended them (Mikloško 2013, p. 34). "Truly spiritual people pick up God's cause and make it their own; they don't just live to see but li ve o u t the ch $u$ r ch, because they cannot do otherwise; they are infused with the life-giving Spirit and for them to live is Christ and to die is gain (Flp 1:21)" (Mádr 1992, p. 52).

\subsection{God's Will and the Cross}

People who put faith first in their lives often use "God's will" as an argument. They accept everything in their life as a "gift" (Neuwirth and Lesňák 2001, p. 21) and they are convinced that for a Christian, suffering does not mean unhappiness (Neuwirth and Lesňák 2001, p. 120). Oto Mádr wrote his famous essay Slovo o této době [A Word About These Times] in 1951 in a hiding place. Sisters of Mercy (Borromeans) in Prague helped him hide; however, he was quickly found, arrested and incarcerated for a long period. The first sentence of his essay reads as follows: "Heads up, brothers and sisters! Our times are not particularly friendly to Christians, but for those Christians who stand on the right footing this is indeed a great and wonderful time for us" (Mádr 1992, p. 209). Mádr reiterates this central idea that a truly humble Christian cannot end up begging God for "better times" because every moment is good. "When are we going to get back to normal? Well, the answer is that normal is always because God is always with us" (Mádr 1992, p. 43).

While in prison we noticed that people of weak faith considered their years spent in prison as lost. But we as priests came to understand that we live in fullness exactly when we accept the path set for us by our Lord. (Mádr 1992, p. 308)

One of the believing heroes of the communist era was definitely the Czech priest Ladislav Kubíček, who wrote an autobiography titled God's Will-Just a Pious Phrase? The correct distinction of God's will, in his view, depends on the acceptance of the Cross (Kubíček 2006, pp. 76-77). As articulated by his student M. Svatošová, "surely many bad things happen against God's will due to malicious action by some people but (...) God handles evil so perfectly that the result is better than it would have been, had no evil ever existed" (Svatošová 2006, pp. 10-11).

\subsection{Faith as a Source of Support and Meaning}

This faith that God has evil in his hands and turns it into something good has become a pillar of hope for imprisoned believers, especially in their worst moments. For many of them, this meant giving up on other false consolations and the decision to cling upon faith only. S. Krčméry, for instance, remembered he avoided the quarrels of prisoners about politics or rumors about the anticipated amnesty. "How much nuisance and ridicule I earned from my fellow prisoners when I ignored and refused to spread such questionable sensations... I have simply based my existence on the faith in God, his power, greatness and love" (Mikloško 2013, p. 179). 
Of course, this was no easy ride or bed of roses. Edigna Bílková, Sister of Mercy of St. Borromeo, was arrested in 1952, among other things, for hiding the prominent priest O. Mádr quoted above. She spent 11 months in prison in inhumane conditions, out of which, 9 months were spent in complete isolation. As she put it, "I had to grapple with my faith... who would ever have thought that? Me struggling with Christ? But there you go! It does get under your skin! (...) Sometimes I found myself yelling at God, but here I am..." (Himmerová 2020, online).

Bohumil Vít Tajovský, a Premonstratensian abbot, was asked in one book interview what faith meant to him during the time in prison:

To put it simply, faith was the biggest support for me in my life. If I didn't have it, I wouldn't be here, that's for sure. So let me be clear: without my faith in God, I would have to give up. The biggest help for me when I was in jail. It gave me certainty that everything has a meaning. If I didn't have this hope, if I lost my faith, I would probably go for a rope around my neck. (Tajovský 2009, p. 449)

\subsection{Personal Maturity}

One of the fundamental qualities found in believing persons who stood up against the communist regime was integrity and personal maturity. Ján Čarnogurský, the first prime minister holding the office after the fall of communism, in his book Vydajú vás [They Shall Deliver You], initially published in 1986 in Bern as samizdat and later republished legally in 1990 under the title Väznili ich za vieru [Imprisoned for Faith], describes how the unsuccessful "Prague Spring" of 1968 led to a spontaneous and natural transition of leadership in the anti-communist resistance from the so-called cultural front (artists, intellectuals, publicists) to believers. One of the reasons was that most of the members of the culture front were willing to present publicly humiliating self-criticism and retreated into their private sphere to preserve at least some sort of their livelihood. Believers, on the other hand, stood up firmly:

All of them were spiritually balanced people with deep faith, they were highly educated and enjoyed natural authority. They were literally the best sons and daughters of our nation. (Čarnogurský 1990, p. 14)

Christian political prisoners enjoyed such a great moral authority that it exposed the wickedness of the persecutors, as acknowledged by R. Letz in his work about a significant Slovak culture philosopher and priest, namely, Ladislav Hanus (Letz 2007, p. 31). A. Neuwirth presented the following comparison on the behavior of believers and nonbelievers in prison:

There was a fundamental difference between them [believers and non-believers] because (I think) the approach to life of these two groups was different even before. Believers were able to cope with their fate although, admittedly, they also may have suffered from temporary phases of depression and despair, but sooner or later they were able to overcome those and find their balance and act as a balancing factor for the community. As for non-believers, for them it was definitely more difficult to cope with all those things. (Neuwirth and Lesñák 2001, pp. 85-86)

\subsection{Humility}

Personal maturity is somehow associated with humility. Of course, believing dissidents would not speak about their humility, but this observation is based on the perception of people around them. For instance, one can find several reports about S. Krčméry speaking of himself as a weak and sinful man. He often asked others to pray for him. The rector of the Trnava university Marek Šmid had this testimony of Silvo covering the last years he was tied to his bed:

When he fell ill he told me he felt he was a weak Christian and a sinful man and asked me to pray for him so that Lord forgives him his sins. His confession was a 
real blow to me, even to the extent that I found the strength not to commit sins for a few days. (Šmid 2012, p. 32)

The nephew of Silvester Krčméry, namely, Vladimír Krčméry, highlighted the humility of another long-time prisoner, namely, A. Neuwirth, who before his arrest had risen in his professional career in period 1947-1950 to become a member of a close team of Professor Karrer, the Nobel prize laureate for chemistry. After returning from prison after a long seven years, he had the strength to resume his activities and return to the frontline of clinical biology.

Over the five years following his release [Silvester Krčméry] managed to train three new professors-because he himself was only allowed to keep his doctoral title; but he did not become bitter about that-on the contrary, he continued sharing his knowledge with others. So three of his teammates became professors, another two doctors, and he sort of was left aside basically to clean the lab. (Krčméry 2001, p. 239)

As for humility from a political perspective, J. Čarnogurský points to an important distinction where he compared Christian dissent with the Charta 77 movement. Whereas members of Charta 77 were actively seeking public attention and support, religious activists sought exactly the opposite. They avoided attention before their arrest and "after they have gone through the trial and served their penalty, all they longed for was to be forgotten as quickly as possible so they could return to what they had been doing before- that is to say what they had been arrested for" (Čarnogurský 1990, p. 136).

\subsection{Internal Freedom}

For believers, personal faith and their affiliation to the church represented an island of freedom in the middle of a repressive totalitarian ocean. Several authors recorded having experienced a strong feeling of freedom during big church events toward the end of the 1980s when ordinary Slovak Catholics developed the confidence to openly stand up against the regime. The pilgrimage to Velehrad in 1985 became truly symbolic. On the 1100th anniversary of the death of Saint Methodius, František Mikloško wrote the following words in the samizdat magazine Náboženstvo a súčasnost' [Religion in Our Time] which was published immediately after the pilgrimage took place: "The youth spent the night in prayer, singing and chanting slogans on the glory of the church and the pope. (...) They expressed that freedom, in the first place, is a state of mind, and they were not ashamed to let themselves be heard that it is the church which brings them this freedom" (Mikloško 2013, p. 21). ${ }^{6}$

"It is for freedom that Christ has set us free" (Gal 5:1). In our context, the words of Saint Paul can be updated to reflect the fact that toward the end of the communist era, those young and bold believers were strong because they were standing on the shoulders of giants who had suffered throughout the 1950s. In his memoirs, Silvester Krčméry describes his routine in prison: he often recited the text of the liturgy by heart in Latin, Slovak and Russian; he also knew the entirety of John's Gospel by heart. Each day of the week he offered his prayers for a particular intention:

At times I was able to push through my 'cause' of being allowed to pray openly. For instance, I prayed while standing at the window with my arms outstretched, just for the matter of self-discipline, and also not to sort of 'fall asleep' or lose my focus, and also to train myself in courage... In those moments I had at least a bit of a feeling that I do not give in to those people; that I am really able to fight for a piece of freedom even here in prison, I was proud that I could offer [to God] something more than my loneliness or spiritual crises. (Krčméry 2014, p. 96)

\subsection{Indivisibility of Faith and Life}

For the heroic witnesses, faith was an integral and inseparable part of human life. Other believers may have routinely suppressed or subdued their appearances from consciousness during communism so they could hide into a kind of "double life", but this 
was something that man and women never resorted to. In this respect, the historian F. Neupauer wrote the following lines about S. Krčméry: "The state police could not believe that Silvo wasn't at least a priest or a secret bishop. Maybe it's because he wasn't a 'dualist' like many other lay persons; he simply refused to detach the sacred from the profane" (Neupauer 2014, p. 9).

In the light of the above, faith was a crucial element of the motivation behind all the political actions of Slovak religious dissent. This is also acknowledged by F. Mikloško in the context of the mass events he helped to organize, and which had an impact on the social and political situation in the late 1980s (such as the pilgrimage to Velehrad, mass pilgrimages in Šaštín and Levoča, petitions for religious freedoms or the so-called Candle Demonstration in Bratislava). Believers pushed for a religious cause in the first place, not political, which is something that the state police failed to realize. When the authorities tried to turn the pilgrimage to Velehrad into a secular "celebration of peace" and the Minister of Culture Milan Klusák held a speech and kept on saying "Constantine and Methodius" without mention of their sainthood, this so infuriated the pilgrims that the crowd started chanting "Saint, saint!" (Mikloško 2013, p. 22). According to F. Mikloško, what we need to do today is to once again pursue this "life with the truth"; Western societies walked astray from this ideal by focusing solely on their economic prosperity, stability and peace, but the West no longer seems to be bothered about truth (Mikloško 2013, p. 212).

\subsection{Driving Force of the Society}

The defense of faith based on the principle "indivisibility" of life was quite naturally complemented by the defense of other freedoms. As noted by the secret bishop J. Ch. Korec: "I have never aspired to do politics and I do not want to do it today. But for me, Christianity is something untouchable! I live it out. When believing or non-believing is at stake, I have no choice! And I want to defend the freedom of others as well" (Korec 1993, p. 243). This idea that "our life in God" is the ultimate albeit indirect solution to the social and economic challenges faced by mankind (Korec 1987, p. 231) was theologically substantiated by O. Mádr, who argued that true missionary love is unthinkable without an "active engagement for the Kingdom of God" (Mádr 1992, s. 43): "God has entrusted this world to the brave, and we want to bring God to the world" (Mádr 1992, p. 211).

These attitudes bore fruit during the period of the so-called normalization after the violent suppression of the Prague Spring. In Slovakia during the 1970s, the banner of freedom and resistance to the normalization regime was picked up in the first place by the church and its structures (Mikloško 2013, p. 152). As emphasized by J. Čarnogurský in his analysis of the transfer of leadership from the "culture front", as we mentioned above, another reason was the unrivaled primacy of Christian ideas within underground spheres:

In Slovakia there exists no real alternative to Christianity; there is no ideological group that could compete with all those members of an array of vibrant religious circles, perhaps with the exception of that entropic mass of their consumerist peers who just hang and do nothing. Indeed, no ideological stream other than Christianity has a relevant base of engaged proponents-and least of all the communists. (Čarnogurský 1990, pp. 14-15)

\subsection{Forgiveness and Reconciliation}

After the collapse of communism in November 1989, the believing heroes took the attitudes of forgiveness and reconciliation. These attitudes were also adopted by Christian politicians ${ }^{7}$. Clearly, an inspiration and, so to speak, the father of this idea was Anton Neuwirth, the honorary chairman of the Christian Democratic Movement (KDH), member of parliament (1992-1994), presidential candidate (1993) and ambassador to the Vatican (1994-1998). In his autobiographical book Liečit' zlo láskou [Healing Evil Through Love] he suggested forgiveness as a philosophical starting point and a plausible attitude for society in general. He learned to adopt this view during and after the Second World War; born to a Jewish family, twelve of his close relatives were deported and murdered in the concentration camps. 
The key to the solution of the 'communist problem' lies in forgiveness. Forgiveness does not suppress the pursuit of justice: through forgiveness, the moral essence of an act does not change. Evil remains evil. What is resolved though is some of the consequences of the evil act but more importantly, the relationship between the perpetrator and the victim changes fundamentally. (Neuwirth and Lesňák 2001, p. 93)

A. Neuwirth, as confirmed by Zoltán G. Meško, forgave his informer Dr. Milár, who after the release of Neuwirth from prison, asked for forgiveness and apologized to Neuwirth. Neuwirth accepted his apology. "This honorable gentleman accepted the hand which used to write all those allegations [against Neuwirth], who reassured him that he had no bad feelings about him" (Neuwirth and Lesňák 2001, p. 237).

Another beacon of forgiveness in the history of post-communist politics in Slovakia is František Mikloško, who was a long-time parliamentarian (1990-2010), chairman of the parliament in the period 1990-1992 and a three-time presidential candidate $(2004,2009,2019)$. As the Speaker of the Parliament in 1990, he launched an initiative to declare November 1st the "Day of Reconciliation". In his ceremonial speech, he urged for reconciliation, which he saw as a prerequisite for the future spiritual and material development of Slovakia (Mikloško 2013, p. 61).

Forgiveness in the name of love became central for many of the believing political prisoners. It was already present in the formulations used in the Open Letter of Catholics Incarcerated for Faith, which was addressed during the Prague Spring to Alexander Dubček, who then served as the First Deputy of the Central Committee of the Communist Party of Czechoslovakia: "We were-and we still are-(...) prepared to suffer for our ideals but also to forgive injustice and work with anyone on anything that is good" (Mádr 1992, pp. 212-13). The underlying motif of such an attitude was love. "Suffering which does not produce love makes no sense" (Neuwirth and Lesňák 2001, p. 89). "The truth of faith was saved through the power of love. It was love that has conquered propaganda and hatred" (Mádr 1992, p. 149).

Love is the key, it has to be pure so that we faithfully endure, work together, suffer, and die for no less than our Lord. Let us love Him but let us not hate 'them'. We can afford a victory without hatred. (Mádr 1992, p. 210)

\section{Conclusions}

Based on an extensive review of Slovak literature on faith and communism and its subsequent quantitative analysis, we presented the qualitative analysis of central ideas contained in the corpus of literature and the role of faith in the struggle against communism. We extracted fourteen categories.

The philosophical underpinnings of our heroic witnesses of faith were discussed in the three sections concerning internal self-discipline in contrast to the sloppiness of consumerism and prosperity; the essence of being human, including the related adversary ideologies; and the non-relativist understanding of the truth and questions related to the "holding" the truth. Believers regard themselves as something more than "mere machines intended for feeding, machines consuming ever greater amounts of food, clothes, cigarettes movies or TV shows", believers aspire "to fulfil themselves in their totality, to live out their lives more fully". Believers "wish to embrace their truly and deeply ingrained convictions, and they want let their lives be permeated by those convictions. That is the true meaning of 'living purposefully'" (Korec 1991, p. 175). At the same time, believers refuse to light a lamp and put it "under a basket" (Mt 5:15), i.e., they refuse to remain passive when faced with evil because passivity in the face of evil is interpreted as silent consent. Believers feel the obligation to defend Christian values, and along with those values, to defend the "moral backbone of the nation" (Mádr 1992, p. 213).

We also addressed questions related to the intimate nature of faith through topics such as personal unity with God, the radical primacy of faith, the unconditional acceptance of God's will and the Cross and faith as a source of spiritual support and meaning. Slovak and Czech heroes of faith surely enjoyed the pleasures of contemplative prayer, when the 
soul is being "drifted away" and detached from sensual experience, including the kind of "weightlessness" that lasts for several days, as described by S. Krčméry, for instance. He experienced such states of mind in prison when praying over the Gospel of John, which he knew by heart (Novak 2014, p. 398). Such a "non-transferable" dimension of one's internal experience of the course of events was recognized, even by liberal dissidents, including the liberal thinker and writer Milan Šimečka in the aftermath of the Candle Demonstration in Bratislava in March 1988. Šimečka noted "it was not just an intellectual or emotional experience but also transcendent" (Mikloško 2013, p. 32). Obviously, such an understanding was quite rare; communists saw no place for the total primacy of faith whatsoever. The example of a farmer named Augustin Navrátil ${ }^{8}$ is more than symbolic. The totalitarian regime was not able to cope with the sturdiness of an engaged Christian; therefore, they eventually decided to confine him at a psychiatric facility and forced submissive doctors to sign a false diagnosis that read: "paranoia querulans" (Drda 2020, online).

Passages on human maturity, humility and internal freedom pointed to some of the qualities of human character of those who endured during communism. O. Mádr, in his philosophical and theological treatise on personality, laid down the definition of a moral personality as a personality that is "ordered permanently toward the good" (Mádr 1992, p. 105). He thinks of a Christian personality as "a special case of moral personality, in which the standards of a Christian moral personality are determined by Christian principles" (Mádr 1992, p. 102). According to Mádr, "Christianity is a specification of religion, and religion is a specification of humanness". This understanding, however, does not lead to pride. On the contrary, it leads to humility, as articulated by S. Krčméry: "During each of my spiritual crises I often made a commitment that I would never reproach people should they fail or give in. Honestly, I would fail as well a long time ago, if God did not hold my hand, if God didn't actually force me to keep up" (Mikloško 2013, p. 180).

The last three sections overlapped with broader social issues: the indivisibility of faith and life, faith as a driving force of social development and the final passage on reconciliation and forgiveness. In the 1950s, O. Mádr wrote that "the virtue of our times" is bravery: "God gave this world to the brave, and we want to bring God to the world" (Mádr 1992, p. 211). As concluded by J. Čarnogurský, communists are mainly managers, career-oriented and compromise-driven people pursuing realpolitik; they are people seeking self-assertion: "in other words, they are far from being dedicated proponents of their own ideology". On the other hand, religious circles, monastic orders and other parts of the "apparatus" of the church are full of "people who know their objective, their path toward the goal, and who are willing to make sacrifices in order to attain it" (Čarnogurský 1990, p. 15). In 1993, Čarnogurský's friend, dissident and political peer F. Mikloško raised a question at one of the conferences organized in the aftermath of the collapse of communism: What should be the next step of the yet unfinished revolution? "We have no previous historic experience with these kinds of revolutions. The only similarities or patterns I can think of can only be found within the realm of Christian thought" (Mikloško 2013, p. 69).

However, what stands above philosophical, intimate, personal and social or political dimension is the idea of self-sacrifice of martyrs. In times of extreme oppression, such sacrifice took on extreme forms. Today it is the beacon in all the vicissitudes of a free society, and admittedly, these are also times when life is not always easy. As concluded by the historian Róbert Letz, for us, the martyrs from the period of communism encourage us to be open to making sacrifices out of love: "Quite often Christians resort to simplification as they regard sacrifice in its highest form-such as the sacrifice of one's life- as the only true sacrifice that exists. However, if they fail to realize that sacrifice takes on many forms including small sacrifices of our everyday lives, then will see it just as an abstract ideal; they will simply keep on dreaming about sacrifices they would never make" (Demko and Letz 2014, online).

It should be noted that the testimonies of martyrs who managed to transcend their desires through personal sacrifices eventually led to a profound change in the whole society. This is an important lesson, "especially today when some historians and publicists tend to reevaluate their views on the normalization regime. They tend to play down courage, faith and 
resilience (...) to the level of banality; as a result, cowardly conformity —or even something more wicked - slowly creeps into the minds and hearts of citizens to become an 'acceptable norm'" (Drda 2020, online).

All the heroes of faith went through the so-called second conversion, which is a spiritual transition from rigid and habitual faith to an enthusiastic personal relationship with God, often inspired by a strong moment of profound spiritual experience or awakening. This became a firm, unshakeable starting point for the believing heroes in their spiritual lives. Many of them related this awakening to a kind of Plato's "enlightenment" (akin to the allegory of the cave). They felt as their special calling and duty to pass on what they had come to understand through their faith. However, it is clear from their testimonies that they did not have any premeditated master plan to bring about a social change or implement a political vision. On the contrary, they tried to live the Gospel in small practical aspects of their everyday lives as ordinary citizens, and by doing so, they somehow became part of something that eventually transcended them. This view was perhaps most succinctly articulated by František Mikloško in his piece written on the first anniversary of the Candle Demonstration, which took place in March $1988^{9}$. In his essay, he addressed the question of what needs to be done at times when a fundamental change in society is imminent: "If we decide to live a life of spirit and prayer then we can be sure that what we do will be blessed just like the gathering in Bratislava on 25th March 1988. We have never stopped thanking God that He helped us discover a new dimension in our souls through that event. It is a dimension which represents a spiritual enrichment for all of us; something that helps us better understand who we are and where we are heading on our earthly journey" (Mikloško 2013, p. 35).

Funding: This research was partially supported by the Nanovic Institute for European Studies, University of Notre Dame, USA.

Institutional Review Board Statement: Not applicable.

Informed Consent Statement: Not applicable.

Conflicts of Interest: The author declares no conflict of interest. The funders had no role in the design of the study; in the collection, analyses, or interpretation of data; in the writing of the manuscript; or in the decision to publish the results.

\section{Notes}

1 The communist coup and takeover of power in Czechoslovakia took place as late as February 1948, but the communist crackdown on the church started to take effect immediately after the end of the war.

2 Common project of Catholic universities in Central and East Europe (Slovakia, Poland, Ukraine, Croatia, Georgia, Hungary) that is led by the Nanovic Institute at Notre Dame University, Indiana, USA.

3 T. Kolakovič was a priest from Croatia, but during his visit to Slovakia and the Czech Republic in the 1940s, he gradually gained reputation and influence and had a remarkable impact on the community of key figures within the circles of the anticommunist resistance, especially thanks to his role as a founder of the "Rodina" movement (The Family).

$4 \quad$ M. Gavenda is the youngest person on the list (b. 1963). Although he had adventurously fled the country in the late 1980s for Rome to become a priest, his main contribution consisted in his later extensive monograph, which was a scientific analysis of the Slovak church during communism, in which he discusses the secret formation of priests in the monastic orders and church communities (Gavenda 2014). The title of his monograph also inspired the title of this article.

5 Foucault regarded truth as something originating solely within "this world". His rejection of the idea of "universal truth" in contrast to the Christian view is discussed in more detail in P. Polievková (Polievková 2013, p. 42).

6 Originally published in Náboženstvo a súčasnost' [Religion In Our Time], 3/1985, pp. 17-19.

7 As part of the Christian Democratic Movement (KDH) established by Ján Čarnogurský in 1990; the party remains a relevant political force in Slovakia to this day.

8 In 1987, A. Navrátil organized the famous 31-bullet petition for religious freedoms in the Czechoslovak Socialist Republic, which was also supported by Cardinal František Tomášek and signed by 600,000 people, half of them Slovaks. Previously, he was imprisoned inter alia for the distribution of an open letter about the insidious murder of the secret priest Přemysl Coufal by the state police.

9 Published as samizdat in Náboženstvo a súčasnost' [Religion in Our Time], vol. 1/1989, pp. 35-37. 


\section{References}

Braxátor, František. 1992. Slovenský Exil 1968 [Slovak Exile 1968]. Bratislava: LÚČ.

Čarnogurský, Ján. 1990. Väznili ich za Vieru [They Imprisoned Them for Their Faith]. Bratislava: Pramene.

de Oliveira, Jefferson R. 2019. The "on and off" of faith in hypermodernity: Religion and the new interfaces of the sacred in the media era. Espaço e Cultura 44: 9-30. Available online: https://www.e-publicacoes.uerj.br/index.php/espacoecultura/article/viewFile/ $47351 / 31467$ (accessed on 29 September 2021).

Demko, Matúš, and Róbert Letz. 2014. Uniká nám obět' všedního života [We miss the victim of everyday life]. Katolický Týdeník 14. Available online: https:/ / www.katyd.cz/clanky/unika-nam-obet-vsedniho-zivota.html (accessed on 29 September 2021).

Desrosiers, Kyle. 2020. Spiritual Reports from Long-term HIV Survivors: Reclaiming Meaning while Confronting Mortality. Religions 11: 602. [CrossRef]

Drda, Adam. 2020. Křest'an “kverulant" [Christian "querulist"]. Pamět' Národa 12: 2. Available online: https:/ /www.pametnaroda.cz/ cs/magazin/pribehy/krestan-kverulant (accessed on 29 September 2021).

Gašpar, Tido J. 1998. Pamäti I [Memoirs I]. Bratislava: Vydavatel'stvo Spolku Slovenských Spisovatel'ov.

Gavenda, Marián. 2014. Fortes in Fide. Skúsenost' a Odkaz Tajnej Kn̆azskej Formácie na Slovensku v Rokoch 1969-1989 [Fortes in Fide. Experience and Legacy of a Secret Priestly Formation in Slovakia in the Years 1969-1989]. Trnava: Dobrá kniha.

Gavenda, Marián. 2016. Spiritual challenges of the visual culture. In Expanding Media Frontiers in the 21st Century: The Impact of Digitalization upon Media Environment. Moscow: MediaMir, pp. 33-36.

Gavenda, Marián. 2017. Odkaz Tajnej Cirkvi [The Legacy of the Secret Church]. Bratislava: Don Bosco.

Gazda, Imrich. 2012. Witnesses of Faith as a Key Element in Media Coverage of Religious Message. Studia Theologica 3: 13-31.

Hagan, John Elvis, Jr. 2021. Investigating Pre-competition Related Discrete Emotions and Unaccustomed Religious Coping among Elite Student-athletes: Implications for Reflexive Practice. Religions 3: 149. [CrossRef]

Himmerová, Kristýna. 2020. S jeptiškami si komunisté nevěděli rady. Perzekuci přijímali jako dar a zkoušku víry [The communists could not cope with the nuns. They accepted persecution as a gift and a test of faith]. Pamět' Národa 26: 7. Available online: https://www.pametnaroda.cz/cs/magazin/stalo-se/s-jeptiskami-si-komuniste-nevedeli-rady-perzekuci-prijimalyjako-dar-zkousku-viry (accessed on 29 September 2021).

Hornig Priest, Susanna. 1996. Doing Media Research. An Introduction. London, Thousand Oaks and New Delhi: Sage.

Chňoupek, Bohuš. 1998. Memoáre in Claris [Memoirs in Claris]. Bratislava: Belimex.

Kolakovič-Poglajen, Tomislav. 1993. Syntetický prehl'ad našej práce [Synthetic overview of our work]. In Profesor Kolakovič. Written by Václav Vaško. Bratislava: Charis, pp. 50-61.

Korec, Ján. 1987. Cirkev Uprostred Problémov. Niekol'ko Pohl'adov (Písané v Montérkach) [The Church in the Midst of Problems. Some Views (Written in Overalls)]. Samizdat: Slovenská Duchovná Služba.

Korec, Ján. 1991. Od Barbarskej Noci II. Listy z Väzenia [The Night of the Barbarians II. Letters from Prison]. Bratislava: Lúč.

Korec, Ján. 1993. Od Barbarskej Noci III. Na Slobode [The Night of the Barbarians II. At Liberty]. Bratislava: Lúč.

Kováč, Dušan, Ladislav Bánesz, Juraj Bárta, Mojmír Benža, Martin Bána, Blanka Brezováková, Jozef Bujna, Viliam Čičaj, Juraj Činčura, Vojtech Dangl, and et al. 1999. Kronika Slovenska. 2. Slovensko v Dvadsiatom Storoči [Chronicle of Slovakia. 2. Slovakia in the Twentieth Century]. Praha: Fortuna Print \& Adult.

Krčméry, Silvester. 1995. To nás zachránilo. [This Is What Saved Us]. Bratislava: Lúč.

Krčméry, Silvester. 2014. Pravdou Proti Moci. Príbeh Muža, Ktorého Nezlomili [Truth against Power. The Story of a Man They Didn't Break]. Bratislava: Artis Omnis.

Krčméry, Silvester. 2015. Vy máte moc, my máme pravdu [You hold the power, we hold the truth]. Postoj 10: 9. Available online: https:/ / www.postoj.sk/5707/vy-mate-moc-my-mame-pravdu (accessed on 29 September 2021).

Krčméry, Vladimír. 2001. Vd'aka za svedectvo i za zachránené deti [Thanks for the testimony and for the saved children]. In Liečit' zlo Láskou [Healing Evil through Love]. Written by Anton Neuwirth and Rudolf Lesňák. Bratislava: Kalligram, pp. $239-40$.

Kubíček, Ladislav. 2006. Božia vôl'a-Zbožná Fráza? [God's Will-A Pious Phrase?]. Bratislava: Karmelitánske Nakladatel'stvo.

Kusý, Miroslav. 1990. Na vlnách Slobodnej Európy [On the Waves of Radio Free Europe]. Bratislava: Smena.

Lettrich, Jozef. 1993. Dejiny Novodobého Slovenska [History of Modern Slovakia]. Bratislava: Archa.

Letz, Ján. 1996. Život v Hl'adaní Pravdy. Vývin Osobnosti a Myslenia [Life in the Search for Truth. Development of Personality and Thinking]. Bratislava: Charis.

Letz, Róbert. 2007. Osobnost' verzus moc [Personality versus power]. Pamät' Národa 2: 22-31.

Lipták, L'ubomír. 1998. Slovensko v 20. Storočí [Slovakia in the 20th Century], 2nd ed. Bratislava: Kalligram.

Mádr, Oto. 1992. Slovo o této Době [A Word about This Time]. Prague: Sofia.

Mikloško, František. 2013. Znamenia Čias [Signs of the Times]. Bratislava: Hlbiny.

Mittelman-Dedinský, Móric. 2001. Na Chrbte Tigra [On the Back of a Tiger]. Bratislava: A. Marenčin-PT.

Neupauer, František. 2014. Pravda, ktorá má silu a odvahu [A truth that has strength and courage]. In Pravdou Proti Moci. Príbeh Muža, Ktorého Nezlomili [Truth against Power. The Story of a Man They Didn't Break]. Written by Silvester Krčméry. Bratislava: Artis omnis, pp. $5-11$.

Neuwirth, Anton, and Rudolf Lesňák. 2001. Liečit' zlo Láskou [Healing Evil through Love]. Bratislava: Kalligram.

Novak, Michael. 2014. Orly letia vysoko [The Eagles Fly High]. In Pravdou Proti Moci. Príbeh muža, Ktorého Nezlomili [Truth against Power. The Story of a Man They Didn't Break]. Written by Silvester Krčméry. Bratislava: Artis omnis, pp. 393-400. 
Ottmar, Vojtech. 1996. Podvratnik [The Subversive]. Trnava: B-print.

Palaščák, Jozef. 2006. Spravodlivost' a Pravda v Živote a Práci Otca Biskupa Jána Chryzostom Korca v Rokoch 1945-1989 [Justice and Truth in the Life and Work of Father Bishop Ján Chryzost Korec in the Years 1945-1989]. Prešov: Petra.

Paul, John, II. 1993. Veritatis Splendor. Encyclical. Available online: https:/ /www.vatican.va/content/john-paul-ii/en/encyclicals/ documents/hf_jp-ii_enc_06081993_veritatis-splendor.html (accessed on 29 September 2021).

Paul, John, II. 1994. Tertio Millennio Adveniente. Apostolic Letter. Available online: https:/ /www.vatican.va/content/john-paul-ii/en/ apost_letters/1994/documents/hf_jp-ii_apl_19941110_tertio-millennio-adveniente.html (accessed on 29 September 2021).

Paul, John, II. 2004. Vstaňte, pod'me! [Rise, Let Us Be on Our Way]. Trnava: Spolok sv. Vojtecha.

Polievková, Petra. 2013. Stereotypnost' ako podstata mediálneho politického diskurzu [Stereotyping as the essence of media political discourse]. Media i Społeczeństwo 3: 41-52. Available online: http:/ /www.mediaispoleczenstwo.ath.bielsko.pl/art/03_Polievkowa. pdf (accessed on 29 September 2021).

Ratzinger, Jozef. 2005. Homily in the Basilica of St. Peter in Mass Pro Eligendo Pontifice (18. 4. 2005). Available online: http: / / papabenedettoxvitesti.blogspot.com/2009/06/santa-messa-pro-eligendo-romano_25.html (accessed on 29 September 2021).

Rončáková, Terézia. 2018. Východisko viery vo verejnom diskurze [Faithe as a Starting Point in the Public Discourse]. Studia Theologica 4: 113-39. [CrossRef]

Rončáková, Terézia. 2021. Faith and Freedom During Communism in Slovakia. An Analysis of the Literature Review and Two Notable Stories. Paper Presented at the Name of the Conference Trauma of Communism, Nanovic Institute, University of Notre Dame, South Bend, Indiana, Online, June 29-July 1. To be published in the conference proceedings.

Seewald, Peter. 2010. Svetlo Sveta. Pápež, Cirkev a Znamenia čias [Light of the World: The Pope, the Church, and the Signs of the Times]. Bratislava: Don Bosco.

Svatošová, Mária. 2006. Čitatel' má právo dozvediet' sa [Čitatel' má právo dozvediet'sa]. In Božia vôl'a-Zbožná Fráza? [God's Will—A Pious Phrase?]. Written by Ladislav Kubíček. Bratislava: Karmelitánske Nakladatel'stvo, pp. 7-14.

Šimečka, Milan. 1990. Obnovenie Poriadku [The Restoration of Order]. Bratislava: Archa.

Šimko, Ivan ml. 1994. Čas pravých činov [Time of True Deeds]. Bratislava: Charis.

Šmid, Marek. 2012. Nauč nás pravej vel'kodušnosti [Teach us true generosity]. In Silvo Krčméry. Edited by František Neupauer. Bratislava: Nenápadní Hrdinovia, pp. 32-33.

Tajovský, Bohumil Vít. 2009. Člověk Musí Hořeti. V Rozhovoru s Alešem Palánem a Janem Paulasem [One Must Burn. In an Interview with Aleš Palán and Jan Paulas]. Kostelní Vydří: Karmelitánské Nakladatelství.

Tížik, Miroslav, and Milan Zeman. 2017. Religiozita obyvatel'ov Slovenska a Postoje Občanov k Náboženstvu. Demokratickost' a Občania na Slovensku II. [Religiosity of the Population of Slovakia and Attitudes of Citizens Towards Religion. Democracy and Citizens in Slovakia II]. Bratislava: Sociologický ústav SAV.

Tkáčová, Hedviga. 2014. Postmodern challenge to the call to love "in truth and action". In Whom, Why, and How One Ought to Love: Biblical and Theological Perspectives on Loving One's Neighbor. Edited by Bohdan Hroboň. Mahtomedi: Vision Slovakia, pp. 99-109.

Valčo, Michal, and Armand J. Boehme. 2017. Christian faith and science. Can science enhance theology? European Journal of Science and Theology 3: 89-97.

Zemko, Milan. 2002. Slovensko-Krajina v Medzičase [Slovakia-A Country in the Meantime]. Bratislava: Kalligram. 